Article

\title{
Technology-Based New Service Idea Generation for Smart Spaces: Application of 5G Mobile Communication Technology
}

\author{
Seonkoo Jeong ${ }^{1}$, Yujin Jeong ${ }^{2}$, Keeeun Lee ${ }^{2}$, Sungjoo Lee ${ }^{3}$ and Byungun Yoon ${ }^{2, *}$ \\ 1 Future Technology \& Strategy Research Laboratory, Electronics and Telecommunications Research Institute, \\ 218 Gajeong-ro, Yuseong-gu, Daejeon 34129, Korea; skj0102@etri.re.kr \\ 2 Department of Industrial \& Systems Engineering, Dongguk University, Pil-dong, 3 ga, Joong-gu, \\ Seoul 04620, Korea; jeongyujin@dongguk.edu (Y.J.); kelee@dongguk.edu (K.L.) \\ 3 Department of Industrial Engineering, Ajou University, Wonchen-dong, Youngtong-gu, Suwon 16499, Korea; \\ sungjoo@ajou.ac.kr \\ * Correspondence: postman3@dongguk.edu
}

Academic Editor: Sehyun Park

Received: 16 August 2016; Accepted: 17 November 2016; Published: 23 November 2016

\begin{abstract}
Innovative technology has made it possible to dramatically change the social and economic environment. In particular, 5G mobile communication technology that radically improves the performance of current technology can renew urban infrastructure, public services, and citizens' lives for the implementation of smart spaces. Although new services need to be generated by such innovative technology, existing technology-based approaches have mostly relied on the intuition of experts rather than a systematic approach. Thus, this paper aims to present a method and process by which technology-based new ideas using $5 \mathrm{G}$ mobile communication technology are generated to realize a connected environment by focusing on technological functions as well as customer value. First, the relationships among technology, value, and service are defined through morphology analysis. Second, service opportunities are identified by developing a transformed buyer-utility map in the smart space environment. After mapping the established services, candidate cells for a new service were identified as vacant cells in the map with the removal of technically unnecessary candidates based upon the pre-defined relationship. Third, a new service idea is generated by modifying/extending candidates concretely through an ERRC (Eliminate, Reduce, Raise, Create) framework. Value factors are determined in advance and shown in the As-Is value curve representing the current status. The current level in the curve is then compared at an industrial level and value factors are chosen to newly modify or create. As a result, the To-Be curve is established and leads to a new service idea. It can be regarded as a useful tool for mobile carriers to plan new business models for smart spaces with adequate technology and market feasibility.
\end{abstract}

Keywords: smart space; business model; new service development (NSD); technology-based service; mobile communication; morphology analysis; value innovation

\section{Introduction}

The impact of information and communication technology (ICT) on cities has been substantial in the digital economy. This technology has transformed methods of efficiently manufacturing products and providing high-quality services, thus changing the lifestyle of citizens in cities. In particular, advancement in mobile network technology facilitates various intelligent services for citizens, including smart homes and smart spaces. Yet the voice call centric service has mainly been offered in the $2 \mathrm{G}$ or $3 \mathrm{G}$ mobile network environment, and data-based services such as video streaming have been developed in the $4 \mathrm{G}$ and $\mathrm{Wi}-\mathrm{Fi}$ network environment. Although $4 \mathrm{G}$ mobile communication 
technology offers fast data transaction for convenient mobile services, the innovative next-generation technology, 5G technology, can realize radical changes for the smart city and smart spaces in particular. Smart space can be defined as hyper-connected and mixed reality space [1]. Mixed reality is the concept of merging real and virtual worlds [2], and a hyper-connected world, suggested by Wellmann [3], is a world in which everyone and everything is or can be connected [4]. While a smart home enables human-machine interaction, then analyzes and uses that information in solving life problems, smart space extends that scope into the social environment to solve potential personal and social problems, providing new value to the world. The scope of a smart space is very broad because new applications have been developed for diverse purposes such as home automation and vehicular network enhancement on ubiquitous computing platforms. The development of 5G technology serves as a pillar to achieve a breakthrough in the transformation of an ICT network infrastructure for smart spaces. However, in the changing landscape of mobile communication, it is necessary to cope with the uncertainty caused by a rapidly changing environment through the development of new technology as well as the transformation of business models for 5G technology. In order to successfully implement and manage smart spaces, innovative technology as well as services should be provided in the process of building smart spaces. Thus, selecting the technology to be adapted to a service is a critical task that influences the success of innovation, and the importance of technology-oriented service innovation has been increasingly emphasized.

With so much interest in innovation, there has been remarkable growth in technology, such as increases in patent applications or paper publications based on the huge amount of investment by firms and governments around the globe [5-10]. However, most of them failed to be commercialized and applied to other technologies, products, or services; thus it has remained untapped as a sleeping technology [5-7]. What was worse, firms and governments frequently experienced failures of commercialization despite technical excellence due to various factors such as low marketability and misunderstandings about the market or customers. There is a gap, called 'chasm', between the expectations of early adopters and the offerings of pioneering firms in the commercialization process of technology $[11,12]$. It must be bridged in order to make more profit and grow the mainstream market. Thus, in order to cross the chasm and accelerate the efficiency of research and development $(R \& D)$ investments, it is essential to investigate applicable areas of technology before embarking on technology developments.

Technology-based services are relatively radical and innovative because their technology platforms have been newly implemented for businesses. Therefore, customers would generally find it difficult to envision future services using these technologies, and staff would similarly struggle to devise innovative ideas for applications based on these technologies [13]. Even though the importance of technology-based services for successful service innovation has increased, most studies have relied on benchmarking advanced cases or experts' opinions subjectively rather than a systematic approach [14]. Specifically, several studies have emphasized the role of the customer and the scope of customer involvement $[15,16]$. They explored the identification of innovative customers and the effectiveness of utilizing them for generating new service ideas in a technology-based service setting [13].

Thus, this study intends to propose a systematic process to create new service ideas in contrast with scenario analysis based upon brainstorming or experts' opinions. This paper proposes an approach to generate new technology-based service ideas for smart spaces based on morphology analysis and value innovation. Morphology analysis can identify the concrete forms of technology associated with requirements of the target technology by dividing a whole system into several dimensions and shapes in each of the dimensions to explore available combinations. It enables generating service ideas by selecting the technology dimensions and shapes. Value innovation is the strategy suggested by Kim and Mauborgne to eliminate the boundaries in an existing market by creating innovative value $[17,18]$. While new services will be derived by relying on technological functions, customer values are simultaneously considered with consideration for existing services. From this viewpoint, the proposed approach is able to narrow the gap between technology and markets 
when planning and developing a new service or business. The approach focuses on technological functions and service value by analyzing and structuring technology systematically and quantitatively as well as simultaneously reflecting the customer value in the customer experience cycle, which divides customers' experiences into six phases from purchasing to maintenance and disposal. In particular, this study aims to create new service ideas on the basis of technology, and thus, which technology or function is able to generate novel services should be investigated earlier. For this, it is necessary to examine functions of new technology through structuring them, which means that technology is divided into functions in detail. In this research, morphology analysis is applied to analyze and make hierarchical structure of technology. At first, technological functions originating in existing services that are able to provide value for customers are identified by inspecting the relationships among technology, value, and service with morphology analysis and scoring. The abovementioned associations are identified by examining which functions and values have been provided to the customer by previous services. Second, new service opportunities are identified by a transformed buyer-utility map that is filled with existing technological services that can offer value for consumers. Third, identified opportunities are modified and elaborated by eliminating, raising, reducing, or creating customer values that the industry has never offered with the pursuit of differentiation and low cost through the value curve and ERRC (Eliminate, Reduce, Raise, Create) framework.

This paper is organized as follows. We begin with an overview of technology-based services, value innovation, and morphology analysis in Section 2. Section 3 focuses on the research framework and shows the overall process for generating technology-based new service ideas in detail. In order to apply the proposed approach to the implementation of smart spaces, new service ideas using $5 \mathrm{G}$ technology are derived in Section 4. Finally, this research is concluded in Section 5 with a general discussion of the findings and their implications for researchers and managers involved in the telecommunications industry.

\section{Background}

\subsection{Technology-Based New Service Idea Generation}

There has long been a lot of debate about push-pull innovation. While the core of the technology push argument is that advances in technology determine the rate and direction of innovation, the other side argues that changes in market conditions create opportunities for innovation [19]. However, technology push and demand pull strategy still cannot be affirmed as the right or wrong approach to innovation; which strategy works best depends on assorted variables [20]. Meanwhile, there is a perspective that one of the differences between technology-driven and market-driven is the level of innovation. Another view describes that technology push can be characterized as disruptive, highly uncertain, and time-consuming for radical innovation, whereas demand pull innovation is relatively certain, substitutable, and continuative for incremental innovation [21-23]. Stefano et al. updated the debate on the sources of innovation to provide a more granular understanding of how technology and demand interact [24]. Thus, great attention has been paid to the technology push and market pull innovation. Meanwhile, there have been some attempts to compare product innovation with service innovation. Nijssen et al. showed that R\&D strength is more important in developing radical new services than new products [25]. Griffin studied how new product and new service development have similar key success factors but different priorities [26]. Möller et al. proposed the characteristics of three types of service innovations (established service, incremental service, and radical service innovation) and an improved collaborative service innovation strategy compared with a client-driven or provider-driven strategy [27]. They especially considered how service innovation links a provider-driven approach with market-driven perspectives rather than focusing on any specific viewpoint. Likewise, there were growing attempts at innovation driven by interactive perspectives, along with studies about the technology push or market pull strategies.

With the increasing importance of technology and service innovation, technology-based service has played an important role in economic growth, since there is growing awareness that differentiation 
based only on technology is insufficient to guarantee success [28]. In particular, the advance of ICT has created numerous opportunities for service innovation as well as new technology-based services that are developed, produced, and distributed, thus making intensive use of ICT [29]. Successful technology-based service ensures that service providers and users create substantial value [30] by reducing risks and maximizing their returns on investments in the new technology [31].

The traditional five-step model [32] and the stage-gate model [33] have been used to develop new products and services as the industry standard and guidelines of the innovation process. These two models, which are not customized depending on a specific situation, are applied to new product and service development procedures. That is why it is difficult to apply these models for some industries that are in rapid technological change and have complex customer needs. In particular, the telecommunications industry needs a customized process for developing new services because it is strongly linked to service convergence with other sectors, such as data service and broadcasting service. Ahn and Skudlark suggested a new service development (NSD) process including uncertainty factors such as the economy, competitors, and technologies based on the telecommunications service development process of AT\&T Laboratories [34]. The proposed six steps are idea generation, concept assessment, feasibility, requirements, development and testing, and deployment. Among these steps, the feasibility phase contained a scenario planning approach, which can capture the uncertainty. The suggested model was verified by a case study on the Phoneweb service using the Internet in 2002. Even though this case was outdated, this research has an implication that the new service development process is structured around the issues of uncertainty and telecommunications industry. Oh et al. proposed service evaluation methods using the Balanced Score Card (BSC) model and Analytic Network Process (ANP) [35]. The BSC model was utilized to identify performance indicators for idea evaluation, and ANP gave priority to selecting the best service among Broadband Convergence Network (BcN), Wideband Code Division Multiple Access (W-CDMA), and Wireless Broadband Internet (WIBRO) in the video telephone services. Prior research focused on decision-making in the new service selection. Also, most of the idea generation methods depend on experts' opinion, brainstorming, facilitation methods, and encouraging new ideas to the organization and customers. According to the global telecommunication study in 2015 [36], the prediction of new service creation was implemented through interviews and surveys with experts from 40 companies about the industry's challenges and opportunities. The global telecommunications study is a worldwide landmark report to navigate the road to 2020 by EY global company. This report suggested that smart home and smart city services associated with the Internet of Things (IoT) are uncertain to receive a high rate of return on investment, whereas over the top (OTT) oriented video services and enterprise cloud are promising services. Ultimately, there has not been much research about the systemic idea generation process, while idea selection processes are actively discussed in the telecommunication fields.

Beyond this, there were attempts to find new service areas through scenario analysis with commonly used techniques such as brainstorming, mind mapping, and morphological analysis. New business opportunities were identified for the next-generation systems beyond 3G communications by using scenarios, but this study did not focus on technological specifications [37]. In addition, new use cases were defined by dealing with market needs on the basis of the new $5 \mathrm{G}$ technology. However, the proposed use cases failed to let customers know which values can be provided through new use cases $[38,39]$.

In recent years, relatively few studies have attempted to explore an approach that generates a new service idea based on technology; however, numerous studies have been carried out with regard to new service development without considering technology itself. Many studies aim to develop a new service concept by exploiting a wide range of methodologies from user involvement and learning from customers to quantitative approaches such as genetic algorithms and agent-based simulation [40-43]. Kim et al. proposed a technology-oriented approach to identifying and managing opportunities for technology-based services through a patent-based portfolio [44]. Because innovation for technology-based services is usually derived from technology in this study, technology was considered 
a source to identify opportunities for technology-based services. Business model patents that include vast amounts of information on real world service innovation based on technology were utilized as data for citation analysis and cross-impact analysis. Opportunities for technology-based services were identified by developing a portfolio map on the basis of the future effect of technology on services.

On the other hand, related literature regarding the technology-based design is reviewed in another perspective of technology-driven approach [28,45-47]. Technology-based design is the most valuable for sustaining economic growth owing to the cumulative nature of technological progress. Thus, Luo et al. focused on the relationship between design and economic value, and insisted that the high capability of technology-based design has a positive effect on long-term economic growth [45]. Similarly, the role of design was addressed when developing technology-based services by investigating cases undertaken in new firms [28]. In the technology-based service development, design processes are concerned with providing a bridge from technical functionalities to value in a finished product or service and contribute to enhancing the value of services [46,47]. Evidence on the role of design in exploiting technology innovations to create attractive services and to facilitate the management of positive relationships with customers was discovered in the firms studied.

Numerous studies dealing with problem solving issues have aimed to solve weaknesses through technology $[48,49]$. For instance, researchers have worked on investigating technological solutions to the problems that customers face [50]. Altshuller developed the Theory of Inventive Problem Solving (TRIZ) by analyzing a number of patents [51]. TRIZ solves technical problems through 40 principles of invention such as segmentation, taking out, and local quality, and a contradiction matrix, which is composed of improving engineering feature (rows), worsening engineering feature (columns), and 40 principles (cells) [51]. There have been many attempts to apply the TRIZ in solution-driven innovation studies. Yamashina et al. suggested a new method that integrated Quality Function Deployment (QFD) and TRIZ to enable the effective and systematic creation of technical innovation for new products [52]. Zhang et al. proposed a service design approach by integrating TRIZ and the conceptual design activities of service development process [53].

On the other hand, another argument suggests that the role of innovative users is to develop successful services [13,54-56]. Findings from some empirical studies on intensified interaction with customers in various companies showed that involving customers will improve the effectiveness of new service development [54,56]. Thomke and Hippel insisted that firms should direct their energies to a small sample of innovative users when discovering and acquiring new technologies, products, and services [55]. Another study questioned whether customer involvement actually functions to generate truly innovative ideas at the earliest stage of a new service development and queried the effectiveness of employing such customers to generate new service ideas in a technology-based service setting [42]. Lee et al. investigated the factors affecting consumers' adoption of technology-based service innovations with two-step estimation [31]. In order to examine the effects of limited accessibility on consumer adoption of technology, two technology-based services were chosen, ATMs and Internet banking, which exist in different stages of the diffusion process whereby knowledge or services spread to other users.

\subsection{Value Innovation}

Kim and Mauborgne suggested the concept of 'value innovation', which is a key principle of 'blue ocean strategy' [48]. They mentioned that technology innovation is neither a prerequisite for value innovation nor the cause of value innovation; in other words, value innovation can occur with or without innovative new technology [48]. The aim of value innovation is to eliminate the boundaries in an existing market by creating a leap in value for buyers and companies, thus overtaking the competition, and it is regarded as a blue ocean strategy [17]. Kim and Mauborgne identified an 'uncontested market space' as a key opportunity for business, and defined approaches that target these markets as 'blue ocean' [57,58]. According to the authors, blue ocean refers to unknown market space, non-existing industries, where there is no competition. On the other hand, red ocean is described 
as a known market that represents all the industries in existence today $[17,57,58]$. Value without innovation tends to focus on value creation on an incremental scale, which improves value but is not sufficient to make the company stand out in the marketplace. Chaoren and Thawatthatree [59] employed a blue ocean strategy and showed how to use value innovation to create competitive advantages and acquire a leader position in the market by IKEA, which is a furniture and home accessory company. Chaoren and Thawatthatree mentioned that IKEA successfully applied the blue ocean strategy and used value creation as the cornerstone for its competitive strategy, improving its production process and developing unique value-based design concept [59]. Another example of applying the blue ocean strategy is Yellow Tail, which is a brand of wine produced by Casella Wine [58]. Yellow Tail appealed to a broad cross section of alcoholic beverage consumers by applying the blue ocean strategy, reducing or eliminating all the factors the wine industry had long competed on-tannins, oak, complexity, and aging-in crafting fine wine.

When deciding how to distinguish themselves from competitors and gain competitive advantages, firms must understand how to create, communicate, and deliver value to customers [60-62]. Customer value has been regarded as a trade-off between benefits and costs [63] to create competitive advantage, and it has been essential to pinpoint the factors that determine value customer experiences from a specific offering and learn how to manage this value over time [61]. While customer value has been traditionally regarded as related to functions and performance derived from products as value-in-exchange, recent studies suggested that customer value emerges in customer value generating processes such as value-in-use [64]. Hence, most firms have adopted customer value-based selling and pricing as well as management [60-64]. Keränen and Jalkala examined the types of customer value assessment strategies that firms adopt in the business market [60].

Specifically, customers may perceive value and utility differently at the time of the purchase, use, and disposal of an offering, such as a product or service [57,65], which is reflected in the buyer-utility map, first suggested by Kim and Mauborgne [66], which is one of the tools for implementing value innovation [57]. Kim and Mauborgne proposed a systematic approach to reducing the uncertainties of innovation and developed three analytic tools, the buyer-utility map, the price corridor of the mass, and the business model guide, by collecting data on more than 100 companies that have successfully innovated to help managers discover a winning business idea [66]. The buyer-utility map is used to describe how consumers experience an organization's specific offerings, thus allowing managers to identify the full range of utility propositions that a product or service can offer [66]. A new product or service is located in one of the 36 cells in the buyer-utility map, which is composed of six rows (the six utility levers) and six columns (the six stages of buyer experience cycle); the map then shows how the new idea creates a different proposition of utility from existing products. On the other hand, there is a different view that this tool is limited to certain sectors such as service development, because the buyer experience cycle is different between product and service [67]. Thus, it should be properly modified to fit a certain domain. If the utility lever or stage is converted, it may be possible to create a new opportunity or to identify the current competitive status and then find a new opportunity. From this viewpoint, our research modifies rows (utility) of the traditional map of customer values, and then aims to discover new service opportunities.

The value curve is the basic component of the strategy canvas, which is a visualization tool composed of the competing factors along the $x$-axis and the offering level along the y-axis [57] and is a graphical depiction of a company's relative performance across key success factors of its industry [68]. The horizontal axis shows the range of factors in which the industry competes and invests, and the vertical axis shows the level offered for buyers across key competing factors. Value factors are elements for value creation in which an organization invests, such as resources, processes, and capabilities that act as the basis of differentiation and competition. The value curve provides an opportunity to escape from or eliminate the competition by capturing the current and future state of activity within a marketplace, thus helping strategists examine value creation and capture opportunities. 
The ERRC framework proposed by Kim and Mauborgne is a useful tool when establishing a future strategy canvas and has four actions that facilitate identifying value elements to be eliminated (E), reduced $(R)$, raised $(R)$, or created $(C)$, thus reconstructing value elements of buyers in crafting a new curve [17]. Mohamed et al. performed exploratory analysis on 14 different agencies using the ERRC framework [69]. Wenzel and Förster examined the blue ocean strategy of IKEA using various blue ocean strategy tools such as value curve, strategy canvas, and ERRC framework [70]. Completing this grid provides several advantages when making a strategy: (1) it drives customers and companies to follow low cost and differentiation at the same time; (2) it immediately flags companies that are only concentrated on increasing and creating value or performance; (3) it helps companies re-think their cost structure as well as product and service design; and (4) it discovers the range of hidden assumptions made in competing $[17,57]$.

Various approaches to identifying new domains by improving service values for customers, such as the Kano model [71], Quality Function Deployment (QFD) [72], and decision trees, have been actively studied in value innovation of service quality. Among these alternatives, the ERRC framework systematically decides to eliminate unnecessary value factors, increase or reduce levels, or create new factors that can facilitate new service concepts by presenting detailed features of new services. These adjustments of value factors are combined and lead to the reconstruction of the value curve, resulting in a new service idea based on emerging technology. Since the customer value plays an important role in defining new service areas, it is crucial to examine which value is provided and satisfied by new services In particular, the area where no services are provided, despite the customers' many needs for experiencing value and satisfaction, can be explored by value proposition. Thus, tools for value innovation, such as the ERRC framework and value curve, are needed to create new service ideas.

\subsection{Morphology Analysis}

Morphology analysis, first suggested by Zwicky [73], is a methodology used to create new ideas from a decomposed system and has been regarded as a design solution for multi-dimensional and non-quantifiable problems. The generic form is known as a morphological matrix, composed of dimensions that define the attributes of a technology and shapes that show possible ways to satisfy attributes. Opportunities for designing or developing systems can exist as a possible configuration and the remainder needs to be evaluated by domain experts.

The majority of studies utilize morphology analysis for engineering and product design [74], technology forecasting and foresight [75,76], and decision-making and policy analysis [77]. In the field of engineering and product design, Prokopska [78] employed this methodology for architectural design and Medina et al. [79] dealt with the design of a robotic laparoscope by introducing weight and preference coefficients with respect to sets of criteria.

Several studies ware recently made to exploit morphological analysis in design technology and a business model. Song et al. not only suggested an approach to predict prioritized directions of innovation but also to create the most promising practical concept design [80]. Im and Cho [81] proposed a methodology supporting the new business model development process where morphology analysis was used for identifying business model alternatives. They considered that the development of new business models is a multi-dimensional and complex problem since diverse aspects such as value proposition, customers, and partners must be considered, and are uncertain and immeasurable. Yoon and Park [82] suggested a keyword-based morphology analysis, where all occupied configurations of technology were identified by mapping the keywords of existing patents into a pertinent morphology. It combined conjoint analysis and used them to identify opportunities and forecast new technology [83,84], while also expanding to develop a technology roadmap [85].

To summarize, morphology analysis is suitable for investigating objects with high complexity or for solving problems where substance is reduced to various combinations of a number of elements [78]. On the other hand, since morphology analysis should identify various dimensions and shapes to offer a desirable combination among alternatives, it is hardly applied to analyze a complex system that has 
a number of dimensions and shapes with a vast amount of data. Despite the limitation, a lot of studies recognize morphology analysis as a technique to create new ideas for service development [80-82]. Since customers do not know what an emerging technology is able to provide, this study aims to describe several functions of technology by combining dimensions and shapes in the morphological matrix. Dimensions and shapes are composed of technological components and their combinations make functions that can create new value for customers.

\section{Research Framework}

\subsection{Basic Concept}

The aim of this paper is to generate a new technology-based service idea for smart spaces through morphology analysis and value innovation. While new ideas or services have been motivated by a customer's needs, they have been inspired in recent times by technological functions for satisfying customer value. In other words, those functions that can offer satisfaction as well as value to customers must be identified for the sake of developing new technology-oriented services. Consequently, the technology is analyzed in advance and functions are structuralized. Then, new services are explored by modifying previous services and creating completely new concepts. The suggested approach intends to deploy new service ideas on the basis of technological functions instead of customers' needs, simultaneously mirroring customer value in the customer experience cycle. As a result, new services will be developed while companies seek to increase customer value and reduce or eliminate poor value.

\subsection{Overall Process}

This study has three modules for the sake of generating new service ideas for smart spaces based on technological function, as shown in Figure 1. The first module is used to define the relationship between technology, value, and service by analyzing technological functions using morphology analysis and the status of similar services currently available in cities. In this module, it is possible to identify which function can provide the customer with values according to the rate of services offered. The second module is used to explore the possible service opportunities by developing a buyer-utility map. The traditional buyer-utility map is transformed by replacing utility levels in the column of the buyer-utility map with customer value to identify service opportunities reflecting the customer experience cycle. The third module finally generates new service ideas based on identified opportunities by modifying previous services or creating new services within the ERRC framework. The detailed process is explained in the following subsection.

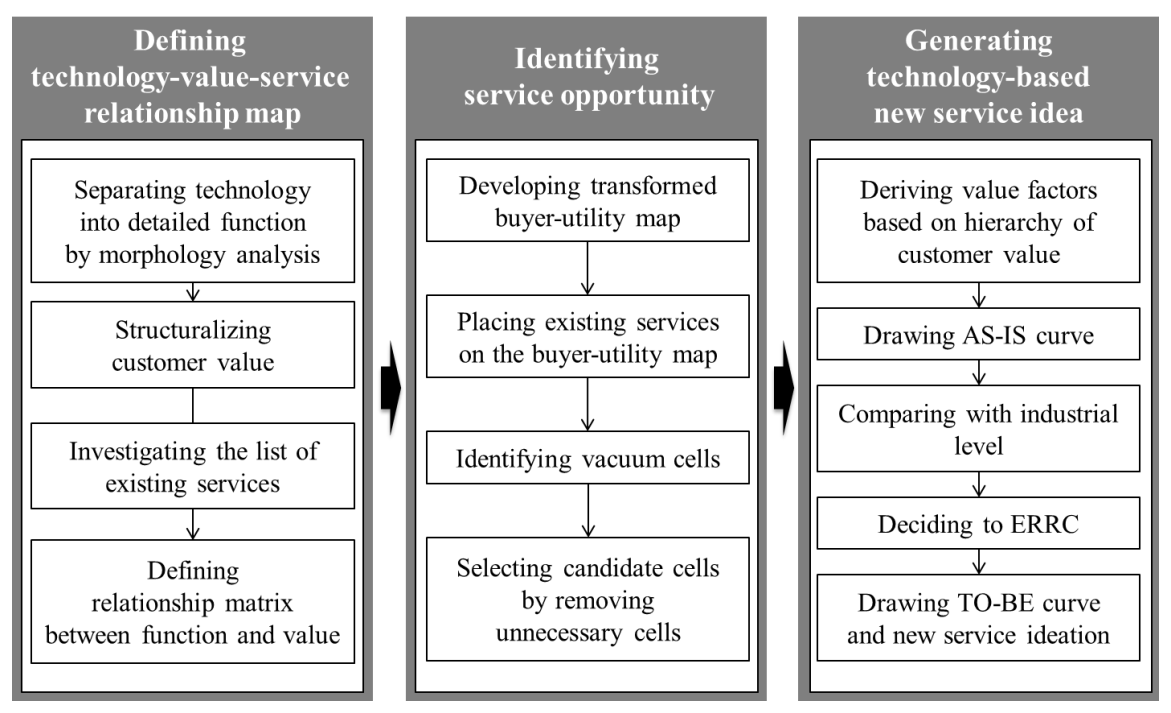

Figure 1. Research framework. 


\subsubsection{Defining Technology-Value-Service Relationship Map}

First, technology and customer value are structuralized in detail to generate new service ideas based on new technological functions while also linking customer value. A technology is separated into detailed functions by determining the dimensions and attributes of the technology in morphology analysis. The possibility of combining detailed functions within the complex functions then enables new customer value and service ideas to be created. After the dimensions and shapes are defined through the literature review related to technology, a morphological matrix on the targeted technology is developed. The available functions that can be embedded into products or services can then be found by combining the shapes for each dimension. All possible combinations of shapes show functions that can be provided through technology, and they are placed on the technology-value-service map as columns. Specifically, the possible functions narrow the range of choice among the many service opportunities, while showing the technological functions.

Next, all customer values are classified into five categories and emotional value is re-classified into personal value and community in detail, as shown in Table 1 . The values that customers are able to experience from services are various because the service might provide different experiences and satisfaction. Since it is too detailed and makes difficult to find new service ideas from each value at the lowest level, this study attempts to establish a hierarchy of values. In other words, the representative values at the category level must be identified earlier than examining the specific and detailed values in order to generate a new service idea in a wide range. Then, it is more appropriate to let customers directly experience different values which are involved in five categories of values from new services. Consequently, we organized all values gathered from the literature related to customer value [86,87]; they are grouped by similar characteristics such as emotional value, epidemic value, economic value, social value, and functional value. Thus, the structure of values is defined as 'the hierarchy of values' in this paper.

Table 1. Hierarchy of values (reorganized with works of Rokeach [86] and Škudienè et al. [87]).

\begin{tabular}{cll}
\hline \multicolumn{1}{c}{ Types of Value } & \multicolumn{1}{c}{ Description } & \multicolumn{1}{c}{ Detailed Customer Value } \\
\hline \multirow{2}{*}{ Economic } & $\begin{array}{l}\text { Values providing economic } \\
\text { utility to customer by } \\
\text { cost-saving, making profit }\end{array}$ & Cost-saving, Profitable \\
\hline \multirow{2}{*}{ Personal } & $\begin{array}{l}\text { Emotions individual customer } \\
\text { can experience through } \\
\text { product and service }\end{array}$ & $\begin{array}{l}\text { Happiness, beauty, Self-control, Capability, } \\
\text { Self-respect, Comfortable life, Relief, Health, } \\
\text { Fun, exciting life, Satisfaction, Courage, a sense } \\
\text { of accomplishment, Love }\end{array}$ \\
\cline { 2 - 4 } Community & $\begin{array}{l}\text { Emotions a community can } \\
\text { feel and experience through } \\
\text { product and service }\end{array}$ & Cheerfulness, Honesty, Safety, Helpfulness \\
\hline \multirow{2}{*}{ Epistemic } & $\begin{array}{l}\text { Values related to increasing } \\
\text { intellectual capability }\end{array}$ & $\begin{array}{l}\text { Intelligent, Wisdom, Rich information, Curious, } \\
\text { Educational, Logic }\end{array}$ \\
\hline \multirow{2}{*}{ Social } & Values provided to society & $\begin{array}{l}\text { Social recognition, Salvation, Equality, Security, } \\
\text { Close relationship }\end{array}$ \\
\hline \multirow{2}{*}{ Functional } & $\begin{array}{l}\text { Values related to function or } \\
\text { features of product and service }\end{array}$ & Available, Unique, Efficient, Effective, Superior \\
\hline
\end{tabular}

A function-value relationship matrix is therefore established by connecting technological functions with customer value in accordance with the existing services (see Figure 2). Before developing the matrix, all kinds of previous services are listed by category through a literature review and web searching, as shown in the upper right corner of Figure 2. The service list includes previous services and provides every possible area for generating new service ideas. This matrix consists of detailed technological functions derived from the morphological matrix as columns and customer value as rows. A correlation between function and value is determined by existing services in the relevant technological field. Which function generates value is determined by whether the value is satisfied 
and achieved by implementing functions. For example, the function related to the data rate in telecommunications technology can achieve a high speed of data transmission between mobile devices. This makes it possible for customers to communicate data without buffering. In other words, customers experience convenience and efficiency when utilizing data communication, and the emotional value and functional value are satisfied by a high data rate. Likewise, previous services providing a specific value to customers are listed, and the proportion is then calculated and scaled in accordance with the average and quartiles. This shows that with a greater number of existing services provided, the degree of association between function, value, and service is increased. In other words, the degree of association between function and value is marked on the relationship matrix according to the scale extracted from the proportion of existing services.

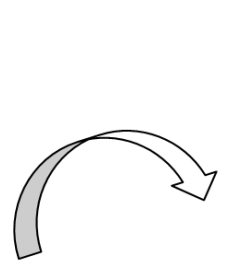

Service list

\begin{tabular}{|c|c|}
\hline Category & Service \\
\hline \multirow{2}{*}{ Education } & Service A \\
\cline { 2 - 2 } & Service B \\
\hline \multirow{2}{*}{ Healthcare } & Service C \\
\cline { 2 - 2 } & Service D \\
\hline$\ldots$ & $\cdots$ \\
\hline
\end{tabular}

\begin{tabular}{|c|c|c|c|c|c|c|}
\hline & $\begin{array}{c}\text { Function } \\
\mathbf{1}\end{array}$ & $\begin{array}{c}\text { Function } \\
\mathbf{2}\end{array}$ & $\begin{array}{c}\text { Function } \\
\mathbf{3}\end{array}$ & $\boldsymbol{\cdots}$ & $\boldsymbol{\cdots}$ & $\begin{array}{c}\text { Function } \\
\boldsymbol{X}\end{array}$ \\
\hline Value 1 & 1 & 2 & 0 & & & 3 \\
\hline Value 2 & 3 & 2 & 1 & \multicolumn{2}{|c|}{$\begin{array}{c}\text { The number } \\
\text { of services }\end{array}$} & 0 \\
\hline Value 3 & 5 & 1 & 1 & & & 0 \\
\hline$\ldots$ & & & & & & 7 \\
\hline Value $\boldsymbol{Y}$ & 0 & 0 & 0 & & & \\
\hline
\end{tabular}

20

\begin{tabular}{|c|c|c|c|c|c|c|}
\hline & $\begin{array}{c}\text { Function } \\
1\end{array}$ & $\begin{array}{c}\text { Function } \\
2\end{array}$ & $\begin{array}{c}\text { Function } \\
3\end{array}$ & $\ldots$ & $\cdots$ & $\begin{array}{c}\text { Function } \\
\qquad X\end{array}$ \\
\hline Value 1 & 0.10 & 0.20 & 0 & \multirow{5}{*}{\multicolumn{2}{|c|}{$\begin{array}{c}\text { The proportion } \\
\text { of services } \\
\text { (= the number } \\
\text { of services/ } \\
\text { total number } \\
\text { of services) }\end{array}$}} & 0.30 \\
\hline Value 2 & 0.30 & 0.20 & 0.10 & & & 0 \\
\hline Value 3 & 0.50 & 0.10 & 0.10 & & & 0 \\
\hline$\ldots$ & & & & & & \\
\hline Value $Y$ & 0 & 0 & 0 & & & 0.70 \\
\hline
\end{tabular}

2

\begin{tabular}{|c|c|c|c|c|c|c|}
\hline & $\begin{array}{c}\text { Function } \\
1\end{array}$ & $\begin{array}{c}\text { Function } \\
2\end{array}$ & $\begin{array}{c}\text { Function } \\
3\end{array}$ & $\cdots$ & $\cdots$ & $\begin{array}{c}\text { Function } \\
\quad X\end{array}$ \\
\hline Value 1 & $\Delta$ & () & & & & 0 \\
\hline Value 2 & 0 & & $\triangle$ & \multirow{2}{*}{\multicolumn{2}{|c|}{$\begin{array}{c}\text { Scaling proportions } \\
\text { of services }\end{array}$}} & \\
\hline Value 3 & (C) & $\Delta$ & $\triangle$ & & & \\
\hline$\ldots$ & & & & & & \\
\hline Value $Y$ & & & & & & 0 \\
\hline
\end{tabular}

Figure 2. The concept of defining a technology-value-service relationship map ( $=$ very strong relation, ( ) = weak relation, $\Delta$ = very weak relation).

\subsubsection{Identifying Service Opportunities}

To identify service opportunities for smart spaces, a buyer-utility map is developed by transforming the utility in the traditional map into customer value, and each cell is filled with relative services in the intersection between the value and customer experience cycle. Relevant services are listed and are then placed into the cells representing the customer value satisfied by the service at the specific stage of the customer experience cycle. In this step, two questions-“"which value is offered?" and "when does a customer experience value in the service cycle?"- - need to be answered. They are extracted from features, demos, and reviews of each service. Features and demos of service acquire the information related to functional value and epistemic value; among them, cost is directly connected with financial value. Feeling keywords in reviews helps to identify the emotional and social value customers attribute to a service at a particular point in time.

After filling in the existing services, a vacuum cell is identified in the buyer-utility map and can be regarded as an opportunity that can be extended to new or advanced services. The row (customer value) and column (customer experience cycle) where the vacuum cell is located will serve as the value factor when developing the value curve in the next phase. 


\subsubsection{Generating New Technology-Based Service Ideas}

Value factors must be derived that correspond to the horizontal axis in the value curve to generate the value curve. They are derived from the value and hierarchy connected with the vacuum cell, or they comprise competitiveness elements compared to other products or services. The As-Is value curve represents the value curve for the previous urban services and is first developed according to the defined value factors; it differs according to the level of value that customers feel and experience. Then, the value factors that can be adjusted or created by new technological functions are defined on the basis of the function-value relationship matrix and buyer-utility map. The ERRC framework is utilized to find ways to regulate the level of value at this step. Four actions can be used to adjust value factors: eliminate, increase, reduce, and create. In other words, a technological function is able to extend the scope of a service by increasing or reducing the level of value or by building a novel service through eliminating or creating the value factors. As previously mentioned, customer values and each phase of the customer experience cycle can be considered as a new value factor for establishing a new service. New or adjusted value factors are thus employed to generate the To-Be curve, which suggests a new service idea through a combination of newly defined value factors.

\section{Generation of Technology-Oriented Services for Smart Spaces}

\subsection{Defining the Technology-Value-Service Relationship Map}

In order to define the technology-value-service relationship map, the morphological matrix for technology was developed, which can provide information related to the emerging technology $5 \mathrm{G}$ technology with which customers may not yet be familiar. Thus, the main objectives of 5G were analyzed considering the challenges and requirements first proposed by major companies and working groups. 5G technology requires eight parameters: user-experienced data rate, peak data rate, latency, mobility, connection density, energy efficiency, spectrum efficiency, and traffic volume density. These parameters were derived as core requirements of the system by the International Telecommunication Union-Radio communication Sector (ITU-R) Working Party (WP) 5D. These parameters are then re-grouped according to similar attributes; for example, user-experienced data rate and peak data rate could be combined to form the objective of "data rate", and mobility and connection density could be joined by the objective of "connectivity". Finally, five objectives were extracted: (1) higher capacity; (2) higher data rate; (3) higher latency; (4) higher connectivity; and (5) higher energy and cost efficiency. Even though these parameters are not entirely new, many organizations focused on quantitatively enhancing technical specifications for parameters like data rate, latency, and so on. At this time, the ways of achieving improved specifications will be diverse, so a morphological matrix will reveal those technical solutions toward the abovementioned objectives distinct from the Beyond 3G.

After identifying 5G vision and core requirements, solutions were defined, as shown in Figure 3, to extract dimensions and shapes in the morphological matrix. Solutions for achieving core requirements (Level 2) lead to the dimensions and technical solutions for 5G (Level 3) correspond to shapes in the morphological matrix respectively. 5G aims to connect everything anywhere, anytime, and in any way in the long run to fulfill the need to increase capacity, data rate, latency, connectivity, and energy efficiency. For example, a few alternatives are given for the following improvements of bandwidth, resource reuse, and increases in spectral efficiency in order to raise the acceptable capacity of traffic, and there are more detailed technical solutions such as the usage of small cells, multiple antennae, and higher frequency. 


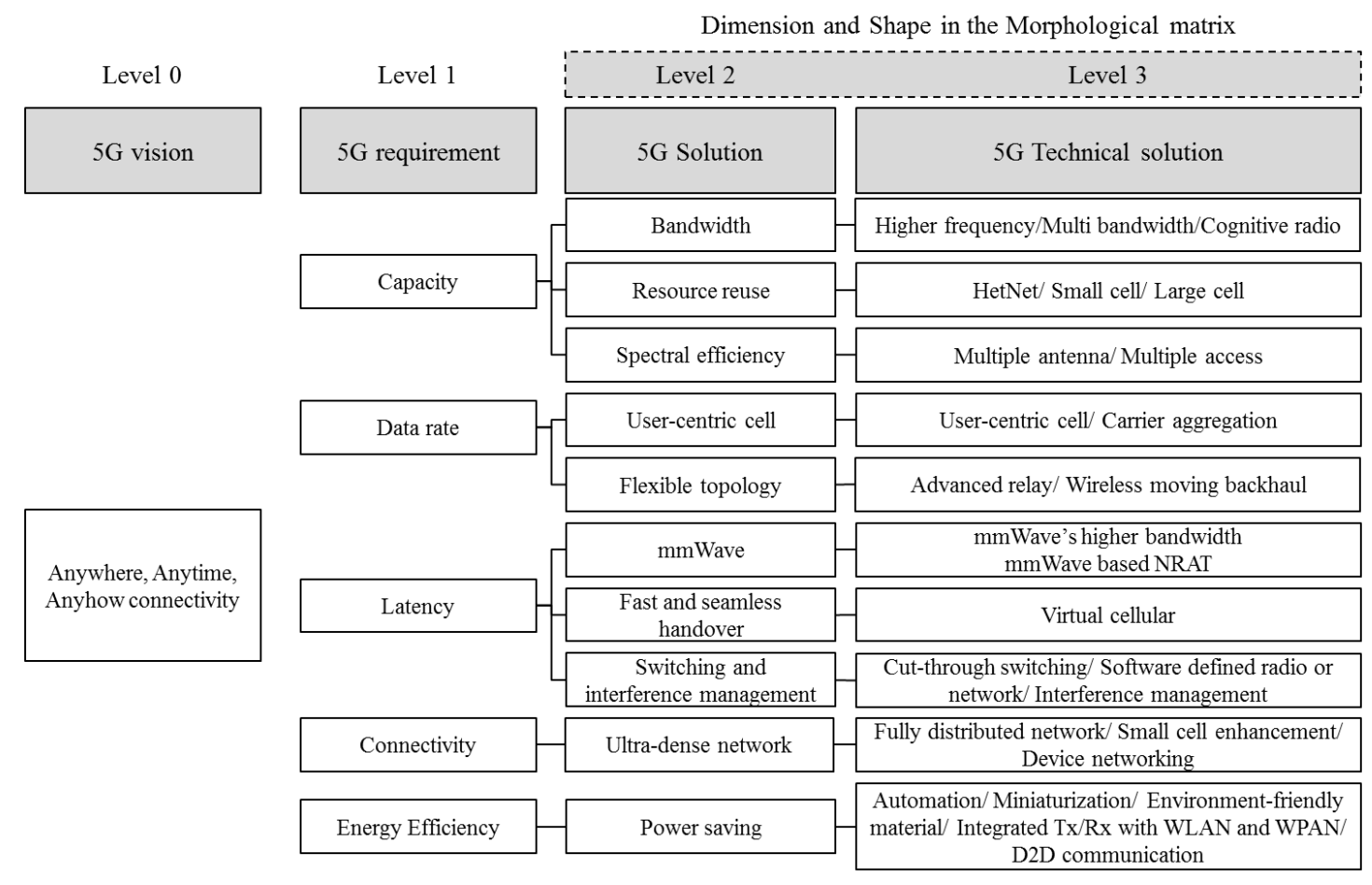

Figure 3. 5G vision, requirements, and solutions.

The morphological matrix of 5G technology was thus determined as shown in Figure 4; it consists of 10 dimensions and two or three shapes that represent the detailed technical solution for each dimension. 14,850 combinations of $(3 \times 3 \times 3 \times 2 \times 3 \times 2 \times 1 \times 3 \times 3 \times 5)$ appeared that are a multiplication of the number of shapes in each dimension, and several combinations were connected to the given functions of 5G technology: Intelligent Self-Organizing Network (SON), Cell-to-Cell communication, Device-to-Device (D2D), Machine-to-Machine (M2M), user-centric contents delivery, and cloud service by removing unrealizable combinations technically or invalid combinations as technological functions. Intelligent $\mathrm{SON}$ aims to automatically configure and optimize the network by grafting the technology of a virtualizing wireless network (handover protocol), which helps to solve inter-cell interference and reduce the high running costs caused by spatial reuse with small cells. Cell-to-Cell communication directly and autonomously deals with signals between network actors who are constructed by the center cell without the intervention of a macro cell in order to decrease traffic, handle local data at a fast rate, and settle shaded communication. 5G systems can rely on a two-tier architecture composed of a macro-cell tier for the base station to device communication and D2D communications [88]. D2D is able to transmit user data directly between terminals without routing via eNodeBs and the core network and has a different structure than the traditional cellular network, which increases spectral efficiency, enhances user experience, and expands communication applications [89]. M2M communications include machines that communicate with each other and exchange information with remote servers, possibly over a cellular network infrastructure [90], and enable the monitoring and support of humans as well as objects and environments involved in remote sites. It is considered the key enabler to provide advanced applications such as smart cities, smart homes, telematics, and industrial device operations by minimizing the interactions between humans for tasks that might be automated. One noticeable function of $5 \mathrm{G}$ is its user-centric content delivery, which shares contents with network actors based on a cell network provided from a source node. This function makes it possible to acquire context information, such as location-based and time-based, without going through the macro cell and to more rapidly deliver data owned by personal cells. Although user-centric content delivery was regarded as beyond the capability of $3 \mathrm{G}$ by Robles et al. (2002), it is more advanced than 5G in reinforcing mobility and personality. 
In 5G communication, the user-centric moving cell will play an important role in delivering contents to users and furthermore establishes an individual network within an independent scope. At this time, the element technology or infrastructure may be distinctive from Beyond 3G. First, although user-centric content was delivered by means of mobile and access router in 3G or the Beyond 3G, the $5 \mathrm{G}$ technology does not require an assistance tool because devices based on 5G perform by themselves. Second, not only do they deliver user-centric contents, but the user's devices act as a sort of server by establishing an individual network independently in 5G. Third, mobility and independence are emphasized more in 5G than in Beyond 3G. Users in 5G can establish the local and independent network, and they transmit and receive contents within this network.

Another function is the cloud service, which enables the data of source nodes to be accessed in the network connected by the cell. This makes it possible to apply data continuously despite the change to other devices. It allows customers to use applications without any installation and access data on any smart device with Internet access [91]. Although few functions have yet received much attention for deploying mobile core network functionalities, they are still useful for achieving higher connectivity anywhere, anytime, and in any way.

\begin{tabular}{|c|c|c|c|c|c|c|c|c|c|c|}
\hline Objective & \multicolumn{3}{|c|}{ Capacity } & \multicolumn{2}{|c|}{ Data rate } & \multicolumn{3}{|c|}{ Latency } & \multirow{2}{*}{\begin{tabular}{|c|} 
Connectivity \\
Ultra \\
dense \\
network
\end{tabular}} & \multirow{2}{*}{$\begin{array}{c}\begin{array}{c}\text { Energy } \\
\text { efficiency }\end{array} \\
\text { Power } \\
\text { saving }\end{array}$} \\
\hline Dimension & Bandwidth & $\begin{array}{l}\text { Resource } \\
\text { reuse }\end{array}$ & $\begin{array}{l}\text { Spectral } \\
\text { efficiency }\end{array}$ & $\begin{array}{c}\text { User-centric } \\
\text { cell }\end{array}$ & $\begin{array}{l}\text { Flexible } \\
\text { topology }\end{array}$ & mmWave & $\begin{array}{l}\text { Fast and } \\
\text { seamless } \\
\text { handover }\end{array}$ & Cut-through & & \\
\hline \multirow{5}{*}{ Shape } & $\begin{array}{l}\text { Higher } \\
\text { frequency }\end{array}$ & Small cell & $\begin{array}{l}\text { Multiple } \\
\text { antennae }\end{array}$ & $\begin{array}{c}\text { User-centric } \\
\text { cell }\end{array}$ & $\begin{array}{c}\text { Advanced } \\
\text { relay }\end{array}$ & $\begin{array}{c}\text { mmWave' } \\
\text { s higher } \\
\text { bandwidth }\end{array}$ & \multirow{5}{*}{$\begin{array}{l}\text { Virtual } \\
\text { cellular }\end{array}$} & $\begin{array}{l}\text { Cut-through } \\
\text { switching }\end{array}$ & \multirow{2}{*}{$\begin{array}{c}\text { Integrated } \\
\text { backhaul } \\
\text { management }\end{array}$} & Automation \\
\hline & $\begin{array}{c}\text { Multi } \\
\text { bandwidth }\end{array}$ & Large cell & $\begin{array}{c}\text { Multiple } \\
\text { access }\end{array}$ & \multirow{4}{*}{$\begin{array}{c}\text { Carrier } \\
\text { aggregation }\end{array}$} & \multirow{2}{*}{$\begin{array}{l}\text { Wireless } \\
\text { moving } \\
\text { backhaul }\end{array}$} & \multirow{4}{*}{$\begin{array}{c}\text { mmWave } \\
\text { based } \\
\text { NRAT }\end{array}$} & & SDR & & Miniaturization \\
\hline & \multirow{3}{*}{$\begin{array}{l}\text { Cognitive } \\
\text { radio }\end{array}$} & \multirow{3}{*}{ HetNet } & \multirow{3}{*}{$\begin{array}{c}\text { Non- } \\
\text { orthogonal } \\
\text { waveform/ } \\
\text { multple } \\
\text { access }\end{array}$} & & & & & \multirow{3}{*}{$\begin{array}{l}\text { Interference } \\
\text { management }\end{array}$} & $\begin{array}{c}\text { Small cell } \\
\text { enhancement }\end{array}$ & $\begin{array}{c}\text { Environment } \\
\text {-friendly } \\
\text { material }\end{array}$ \\
\hline & & & & & \multirow[t]{2}{*}{$\begin{array}{c}\text { Beam } \\
\text { switching }\end{array}$} & & & & \multirow[t]{2}{*}{$\begin{array}{c}\text { Device } \\
\text { networking }\end{array}$} & $\begin{array}{c}\text { integrated } \\
\text { Tx/Rx } \\
\text { with } \\
\text { WLAN } \\
\text { and WPAN }\end{array}$ \\
\hline & & & & & & & & & & $\begin{array}{c}\text { D2D } \\
\text { communication }\end{array}$ \\
\hline
\end{tabular}

Figure 4. Morphological matrix of 5G.

Based on functions of 5G, a technology-value-service relation map was defined, as shown in Table 2, which was made up of "function" columns and "value" rows, where each cell was filled with existing services. Services that have been provided under the $3 \mathrm{G}$ or $4 \mathrm{G}$ networks were investigated on the basis of the standard industry classification as shown in Table 2. In this paper, 'service' means the wide range of values provided to customers through various functions implemented on the basis of telecommunications technology. Thus, services that are based upon mobile communications technology for delivering services and interacting with customers were chosen in Table 2. As a result, 42 services were derived from the information and communications areas of arts, sports, and recreation, and then they are matched with the uppermost table in Figure 5.

Each service was mapped by relevant functions that might be applied and values that this service is able to offer customers (See Figure 5). At this time, services can be duplicated in the matrix because a service does not provide only one function; in other words, each service might have multiple functions. As a result, the number of services satisfying specific functions is recorded on the first matrix in Figure 5. The proportion of the existing service to the whole services was then calculated through dividing the number of all services by the number of existing service, and a relationship map was produced by scaling on the basis of quartiles (Figure 5). For example, the first cell in the first column, 
satisfying emotional value and depending on intelligent $\mathrm{SON}$, is filled with just one service, 'smart city'. Thus, the cell in the same position of the function-value map (see the uppermost table in Figure 5) is filled with ' 1 '. Then, the proportion is calculated to compare each cell in the form of normalization. As a result, the value of the cell in the first cell of the first column is $0.010416667(=1 / 42)$, calculated by dividing the number of services by the total number of services (see the middle table in Figure 5). If the proportion is larger than the third quartileof normalized proportion, there is a very strong relationship between function and value, represented as " $\bullet$ ". Likewise, if the portion of existing services is larger than the average, but smaller than the third quartile of normalized proportion, it can be evaluated as a weak relationship between them and is assigned "O". The mark " $\Delta$ " shows a relatively weak relationship compared to the other services and is involved in the range from median to average, and the remainder were judged to have no relationship between function, value, and service, as shown in Figure 5.

Table 2. The list of services satisfying value and implemented by basis function.

\begin{tabular}{|c|c|c|c|c|c|c|}
\hline & Intelligent SON & $\begin{array}{c}\text { Cell-to-Cell } \\
\text { Communication }\end{array}$ & D2D & M2M & $\begin{array}{l}\text { User-Centric } \\
\text { Contents } \\
\text { Delivery }\end{array}$ & $\begin{array}{l}\text { Cloud } \\
\text { Service }\end{array}$ \\
\hline $\begin{array}{l}\text { Emotional } \\
\text { value }\end{array}$ & Smart city & & $\begin{array}{l}\text { NFC payment; } \\
\text { Intelligent bedside } \\
\text { system; Bubblino; } \\
\text { Pet tracker ... }\end{array}$ & $\begin{array}{l}\text { Smart building; Smart } \\
\text { city; Smartthings; } \\
\text { AgileTrac; AeroScout; } \\
\text { Pet tracker ... }\end{array}$ & $\begin{array}{l}\text { Live } \\
\text { broadcasting; } \\
\text { Moodle; } \\
\text { Edmodo; } \\
\text { BlackBoard; } \\
\text { SumTotal ... }\end{array}$ & $\begin{array}{l}\text { Moodle; } \\
\text { SumTotal ... }\end{array}$ \\
\hline $\begin{array}{l}\text { Epistemic } \\
\text { value }\end{array}$ & & & Moodle & Moodle & $\begin{array}{l}\text { Moodle; } \\
\text { Edmodo; } \\
\text { SumTotal ... }\end{array}$ & $\begin{array}{l}\text { Moodle; } \\
\text { Edmodo; } \\
\text { SumTotal ... }\end{array}$ \\
\hline $\begin{array}{l}\text { Economic } \\
\text { value }\end{array}$ & $\begin{array}{l}\text { Smart city; } \\
\text { Automatic } \\
\text { brightness control } \\
\text { system; Smartgrid } \\
\ldots\end{array}$ & & $\begin{array}{l}\text { Automatic } \\
\text { brightness control; } \\
\text { NFC payment ... }\end{array}$ & $\begin{array}{l}\text { Smartthings; } \\
\text { Electrical lighting and } \\
\text { management system } \\
\ldots\end{array}$ & & \\
\hline Social value & $\begin{array}{l}\text { Smart clean } \\
\text { system; Smart } \\
\text { broadcast control } \\
\text { system; Smart } \\
\text { safezone ... }\end{array}$ & & $\begin{array}{l}\text { Automatic } \\
\text { brightness control } \\
\text { system; Real-time } \\
\text { vehicle control } \\
\text { system }\end{array}$ & $\begin{array}{l}\text { AgileTrac; AeroScout; } \\
\text { Intelligent traffic } \\
\text { system ... }\end{array}$ & & \\
\hline $\begin{array}{l}\text { Functional } \\
\text { value }\end{array}$ & $\begin{array}{l}\text { Smart city; } \\
\text { Building energy } \\
\text { management } \\
\text { system ... }\end{array}$ & & $\begin{array}{l}\text { Automatic } \\
\text { brightness control } \\
\text { system; Google } \\
\text { glass ... }\end{array}$ & $\begin{array}{l}\text { Smart building; Smart } \\
\text { city; Smartthings; } \\
\text { Builidng energy } \\
\text { management system } \\
\text {... }\end{array}$ & $\begin{array}{l}\text { Smart watch; } \\
\text { Google glass; } \\
\text { OnStar }\end{array}$ & Smart watch \\
\hline
\end{tabular}




\begin{tabular}{|c|c|c|c|c|c|c|}
\hline $\begin{array}{c}\text { The number } \\
\text { of services }\end{array}$ & $\begin{array}{c}\text { Intelligent } \\
\text { SON }\end{array}$ & $\begin{array}{c}\text { Cell-to-Cell } \\
\text { communication }\end{array}$ & D2D & M2M & $\begin{array}{c}\text { User-centric } \\
\text { contents delivery }\end{array}$ & $\begin{array}{c}\text { Cloud } \\
\text { service }\end{array}$ \\
\hline Emotional value & 1 & 0 & 4 & 6 & 1 & 0 \\
\hline Epidemic value & 0 & 0 & 1 & 1 & 6 & 6 \\
\hline Economic value & 5 & 0 & 2 & 5 & 0 & 0 \\
\hline Social value & 3 & 0 & 2 & 11 & 0 & 0 \\
\hline Functional value & 14 & 0 & 8 & 16 & 3 & 1 \\
\hline
\end{tabular}

Calculating the proportion of services

\begin{tabular}{|c|c|c|c|c|c|c|}
\hline $\begin{array}{c}\text { The proportion } \\
\text { of services }\end{array}$ & $\begin{array}{c}\text { Intelligent } \\
\text { SON }\end{array}$ & $\begin{array}{c}\text { Cell-to-Cell } \\
\text { communication }\end{array}$ & D2D & M2M & $\begin{array}{c}\text { User-centric } \\
\text { contents delivery }\end{array}$ & $\begin{array}{c}\text { Cloud } \\
\text { service }\end{array}$ \\
\hline Emotional value & 0.010416667 & 0 & 0.04 & 0.063 & 0.010416667 & 0 \\
\hline Epidemic value & 0 & 0 & 0.01 & 0.01 & 0.0625 & 0.0625 \\
\hline Economic value & 0.052083333 & 0 & 0.02 & 0.052 & 0 & 0 \\
\hline Social value & 0.03125 & 0 & 0.02 & 0.115 & 0 & 0 \\
\hline Functional value & 0.145833333 & 0 & 0.08 & 0.167 & 0.03125 & 0.010416667 \\
\hline
\end{tabular}

\begin{tabular}{|c|c|c|c|c|c|c|}
\hline $\begin{array}{c}\text { Relationship } \\
\text { map }\end{array}$ & $\begin{array}{c}\text { Intelligent } \\
\text { SON }\end{array}$ & $\begin{array}{c}\text { Cell-to-Cell } \\
\text { communication }\end{array}$ & D2D & M2M & $\begin{array}{c}\text { User-centric } \\
\text { contents delivery }\end{array}$ & $\begin{array}{c}\text { Cloud } \\
\text { service }\end{array}$ \\
\hline Emotional value & $\Delta$ & & $\odot$ & $\bullet$ & $\Delta$ & \\
\hline Epidemic value & & & $\Delta$ & $\Delta$ & $\bullet$ & $\bullet$ \\
\hline Economic value & $\odot$ & & $\Delta$ & $\odot$ & & \\
\hline Social value & $\odot$ & & $\Delta$ & $\bullet$ & $\bullet$ & \\
\hline Functional value & $\bullet$ & & $\bullet$ & $\bullet$ & & $\Delta$ \\
\hline
\end{tabular}

Figure 5. The process and result of technology-value-service relationship map $(\bullet=$ very strong relation, (0) = weak relation, $\Delta$ = very weak relation).

\subsection{Identifying Service Opportunities for Smart Spaces}

After defining the relationship between function, value, and service, new service opportunities were identified by deploying the buyer-utility map according to the category of education among various service categories, as can be seen in Table 3. Even though this study is limited to an education service area in order to illustrate the process of creating new service ideas, more services can be generated by exploring other service categories.

Five services were selected—ATutor [92], Edmodo [93], Moodle, Sakai [94], and Sumtotal [95]—in the education category. Those are in the top 10 LMS Softwares surveyed by Capterra [96] and commonly chosen in the literature $[97,98]$. The survey conducted by Capterra determined the rank of LMS from the three viewpoints-the number of customers, active users, and online presence. They belong to the e-learning management system or open source-based learning system and encourage students as well as workers to study and strive for self-improvement.

Table 3. Buyer utility map of education services.

\begin{tabular}{|c|c|c|c|c|c|c|}
\hline $\begin{array}{lll} & \text { Cycles } \\
\end{array}$ & Purchase & Delivery & Use & Supplements & Maintenance & Disposal \\
\hline Emotional value & & & $\begin{array}{l}\text { ATutor; Edmodo; } \\
\text { Moodle; Sakai; } \\
\text { Sumtotal }\end{array}$ & & ATutor & \\
\hline Epistemic value & & & $\begin{array}{l}\text { ATutor; Moodle; } \\
\text { Sakai; Sumtotal }\end{array}$ & & & \\
\hline Economic value & Moodle & & & & Moodle & \\
\hline Social value & & & ATutor & & & \\
\hline Functional value & & $\begin{array}{l}\text { Edmode; } \\
\text { Sumtotal }\end{array}$ & Sumtotal & & $\begin{array}{l}\text { ATutor; } \\
\text { Edmodo }\end{array}$ & \\
\hline
\end{tabular}


Which value is provided to customers at a specific stage of buyer experience cycle is defined with reference to the features and demos offered by their websites. The buyer experience cycle is the column of the buyer utility map, which means the cycle that the customer experiences from purchasing services to discarding them. This cycle is divided into six stages: purchase, delivery, use, supplements, maintenance, and disposal. In the case of the education service, most of them can offer convenience to users (students, lecturers, and administrators) because users have easy access to learning by utilizing both web and mobile applications in the 'use' stage of the buyer experience cycle. Edmodo and Sumtotal provide services based on applications, so they have the advantage of enabling users to access the system more easily and offer functional value such as the availability to monitor anywhere and anytime. Lecturers are easily able to check and monitor students' attendance and performance because they are uploaded in real time based on the web application. Since the ultimate goal of the smart learning system is to support learning for users, a system offering huge amount of lectures of superior quality can provide epistemic value such as 'intelligence' and 'rich information'.

As can be seen, education services have a lower economic value compared with other values because it is still expensive to buy a solution with supplementary devices and it is difficult to disseminate systems for all institutions. Moodle is cheaper than other services, so it is mapped on the "purchase" and "maintenance" stage with economic value. From the viewpoint of the buyer experience cycle, almost all customers feel value in the "delivery" and "use" stage intensively. As a result, new service opportunities are discovered in vacant cells that are identified in the "purchase", "supplements", "maintenance", and "disposal" stages of the cycle; moreover, new opportunities may need to acquire economic value, which is achieved by intelligent SON, D2D, and M2M functions with reference to the relationship maps mentioned above. The online learning contents system in disposal stage sifts outdated, personal, and dummy data for data storage management after terminating service. Thus, the buy utility map can successfully position existing services in a cell and explore new service ideas which can satisfy customer value at the specific stage of buyer experience cycle through investigating vacuu, cells in the map.

\subsection{Generating New Technology-Based Service Ideas}

For the purpose of elaborating service opportunities to a new service concept, an ERRC framework was applied and an advanced To-Be value curve was drawn after the As-Is value curve based on the value of the hierarchy. Thus, value factors were preferentially derived and the level of value recognition was evaluated, which were presented as value curves.

The value factors were extracted on the basis of the value hierarchy as follows: "cost-savings", "purchase of complementary goods", "interaction with students", "easy to use", "limited space", and "limited time" (See Figure 6). Few cost benefits were gained since it is necessary to purchase a smart device and a number of contents; furthermore, supplementary assets must be purchased due to the absence of a service platform, and additional expenditure is made for contents due to the difficulty of creating contents for teaching. When relevant hardware or software is broken, it is difficult to respond immediately because lecturers may be unaware of mechanical defects related to hardware and software, thus making it difficult for them to identify fundamental problems that continue to interfere with schoolwork. 


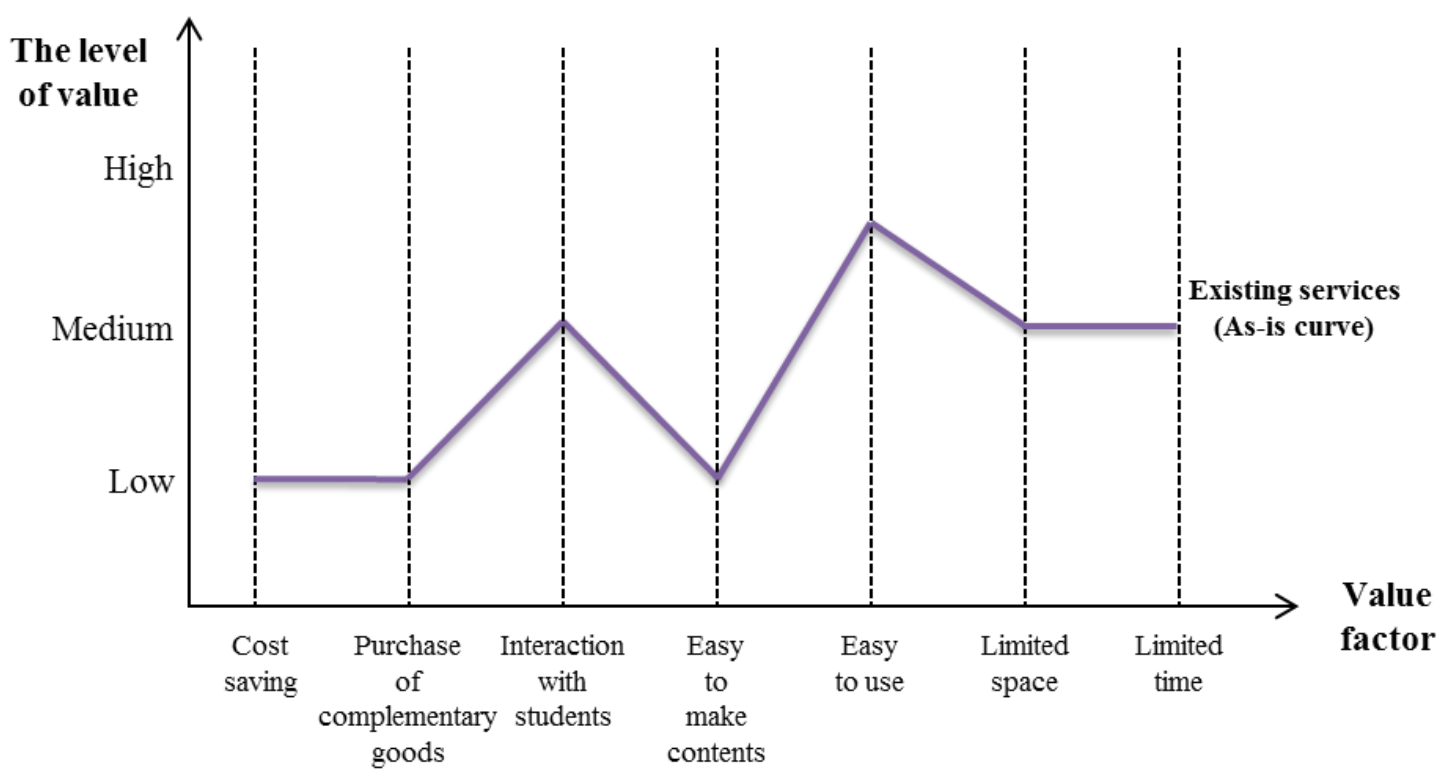

Figure 6. As-Is curve of education services.

This was reflected in the As-Is value curve and applied to the ERRC grid (See Table 4) in order to adjust the level of value curve and create a To-be curve, which led to a new service concept. The ERRC grid consists of adjustable value factors, technological functions, and customer value, while value factors are modified by the relationship map, showing the functions that can provide specific value. After selecting a value factor that should be adjusted by ERRC framework and deciding ERRC action, which value is associated with the value factor was investigated. Then, the technological function related to the value is extracted according to the technology-value-service relationship map (the lowermost table in Figure 5). Suppose that the 'cost-saving' factor should be raised. This factor is related to economic value among customer values by intuition, and economic value is highly correlated to Intelligent SON and M2M function, as shown in Figure 5. That is to say, economic value is improved by implementing intelligent SON and M2M function in service, which helps to save costs when using the service.

Table 4. ERRC grid of education services.

\begin{tabular}{llllll}
\hline \multicolumn{1}{c}{ Eliminate } & & \multicolumn{2}{c}{ Raise } \\
\hline Value factor & $\begin{array}{l}\text { Technological } \\
\text { function }\end{array}$ & $\begin{array}{l}\text { Customer } \\
\text { value }\end{array}$ & Value factor & $\begin{array}{l}\text { Technological } \\
\text { function }\end{array}$ & Customer value \\
\hline- & - & \multicolumn{1}{c}{$\begin{array}{l}\text { Interaction with } \\
\text { students }\end{array}$} & M2M, D2D & Emotional value \\
\hline Reduce & & & \multicolumn{1}{c}{ Create } & \\
\hline Value factor & $\begin{array}{l}\text { Technological } \\
\text { function }\end{array}$ & $\begin{array}{l}\text { Customer } \\
\text { value }\end{array}$ & Value factor & $\begin{array}{l}\text { Technological } \\
\text { function }\end{array}$ & Customer value \\
\hline $\begin{array}{l}\text { Purchase of } \\
\text { supplementary }\end{array}$ & $\begin{array}{l}\text { Intelligent } \\
\text { SON, M2M }\end{array}$ & Economic value & $\begin{array}{l}\text { Defects detection \& } \\
\text { Remote maintenance } \\
\text { in real time }\end{array}$ & $\begin{array}{l}\text { Intelligent SON; } \\
\text { D2D, M2M }\end{array}$ & $\begin{array}{l}\text { Economic value; } \\
\text { Functional value }\end{array}$ \\
\hline \multirow{2}{*}{$\begin{array}{l}\text { Limited time \& } \\
\text { space }\end{array}$} & Intelligent SON & $\begin{array}{l}\text { Functional } \\
\text { value }\end{array}$ & Mirroring & $\begin{array}{l}\text { Intelligent SON; } \\
\text { D2D, M2M }\end{array}$ & Economic value \\
\cline { 2 - 5 } & & Platform deployment & M2M, Cloud & $\begin{array}{l}\text { Economic value; } \\
\text { Functional value }\end{array}$ \\
\hline
\end{tabular}

Consequently, the purchase of complementary goods must be reduced with the aid of intellectual SON and M2M, which support and monitor personal devices without additional complementary assets, thus promoting increases in economic value. Secondly, it is possible to share materials for 
lectures saved in each device through mirroring display without additional process for uploading contents; this can be implemented by intelligent SON, D2D, and M2M. This is newly created and provides economic value by removing additional purchasing and up/downloading for teaching materials. Other factors such as defect detection and remote maintenance in real time are also added to the above functions in order to offer economic and functional value such as efficiency and effectiveness. Faults in software/hardware can be monitored in real time, and managers can then recognize and fix them remotely. Moreover, interaction with students can be increased by M2M and D2D functions that encourage connections between teachers and students and thus offer emotional value to customers.

In summary, the new service concept in education has new or improved features and offers value as follows (see Figure 7): (1) provides an e-learning management platform and simultaneously reduces the purchase of complementary goods; (2) enhances connectivity anywhere, anytime, and in any way by enabling easier 1:1 communication based upon D2D or M2M; (3) increases values in limited areas by building a network automatically for lecturers; and (4) enables the detection of faults and can remotely repair them using M2M with a user-centric cell by giving a signal for oneself. These features give rise to a new service concept, the "smart learning platform", implemented by 5G technology. At first the new service changes several parts such as the modularization of the product because the platform serves as a basic guideline for creating content, which leads to reduced expenses for upgrading systems. Second, the use of D2D or M2M in 5G technology allows all devices to connect anytime and anywhere. Lecturers are able to communicate with all students, which leads to improving students' capability. Third, the lecturers automatically construct their own network, which makes it more convenient to exchange content with other lecturers as well as students in real time when they access the specific network that lecturers have already built. Fourth, the new service is able to detect and monitor in real time. Any defects can be reported to the management team and repaired instantly using the remote support system.

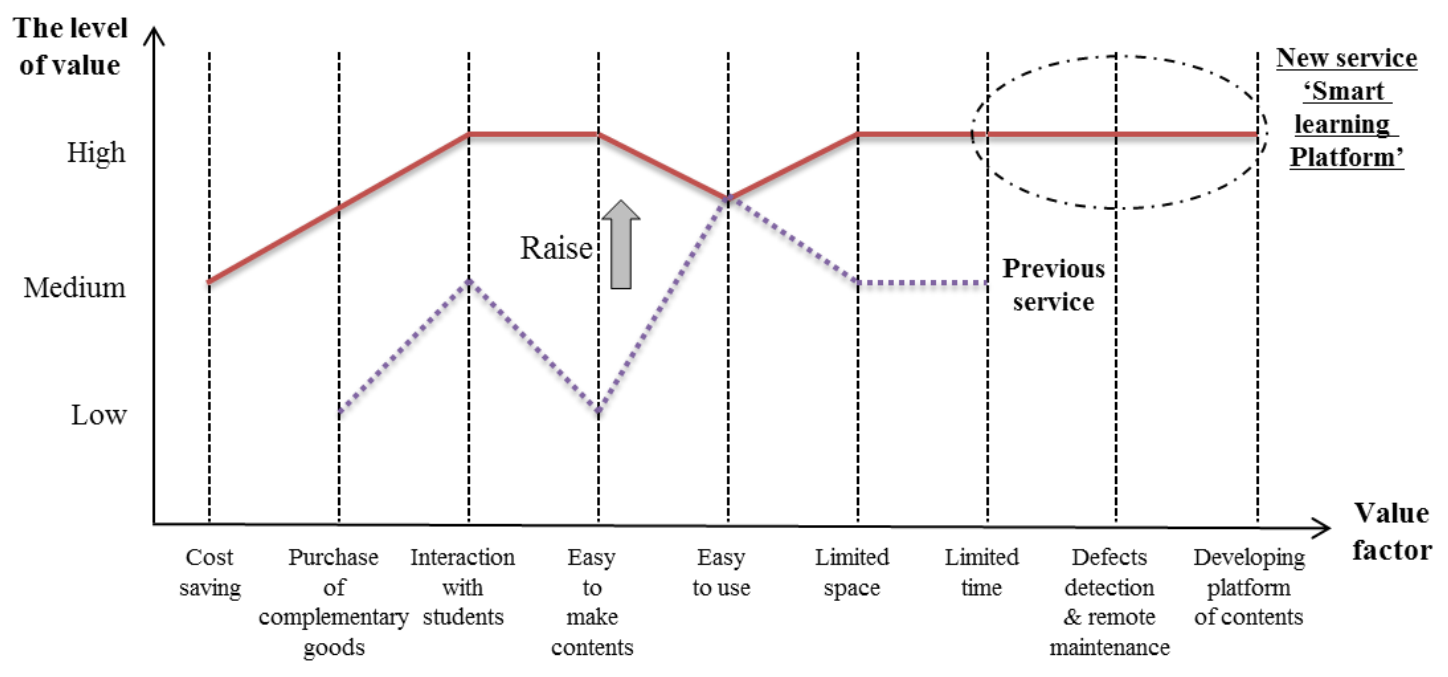

Figure 7. To-be curve (value curve of new service 'smart learning platform').

\subsection{Service Scenario}

In order to illustrate the service process, we assumed a case that can occur in a lecture room, as shown in Figure 8. All lecturers and students possess mobile devices with user-centric moving cells tand utilize devices during lectures. When a lecturer enters a room for teaching, (s)he establishes a locally independent network in a limited open space, enabled by a user-centric moving cell. Within the scope of the network, the lecturer transmits learning materials and receives the status of students, which is implemented by D2D, M2M, and user-centric content delivery functions. In particular, lecture materials are designed on the basis of a content platform with add-ons; this may also be open to students who attend a class only through the independent network or to anyone interested in the 
lecture through a core network. It is possible to check and monitor the status of students such as grades and progress rate in real time, which leads to parents being able to control students more effectively. The interaction between lecturers also enables them to share diverse information about students, lectures, and so on. It is useful for lecturers as well as administrators to manage educational equipment so as to have the latest information related to equipment in the classroom. In addition, communication between devices makes it possible to detect failures in real time and maintain facilities.

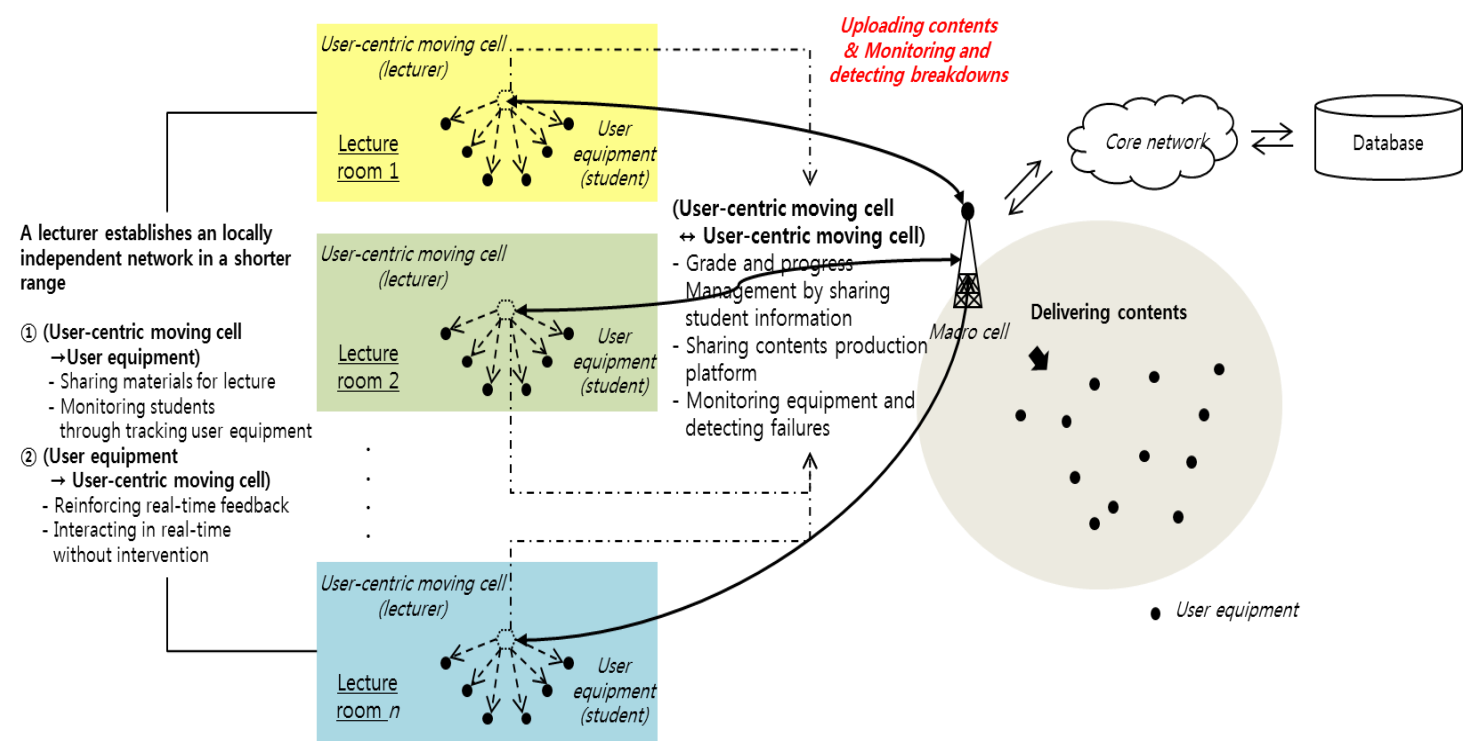

Figure 8. Service scenario based on 5G technology in a lecture room.

\section{Conclusions and Future Research}

As we have seen, this paper suggests an approach to generating new technology-based service ideas for smart cities by using morphology analysis, which is used to deploy technological functions and value innovation that are applied to generate new service ideas based on technology. An attempt was made to initiate new services by focusing on detailed functions of emerging technology and values which customer directly experiences rather than the voice of customers. Before elaborating on the new service idea, a relationship map between technology, customer value, and services was developed by analyzing previous services and their value offered. And then, this map was exploited for generating new service ideas. We then concentrated on customer value, which is provided by implementing specific services to find new value factors, and existing values were additionally adjusted. This led to a new service idea using the ERRC framework with attributes of functions.

Specifically, 5G technology was applied to the development of smart spaces because it has attracted public attention due to its ability to deal with the increases in data traffic caused by the use of innumerable smart devices. In addition, mobile convergence services, such as healthcare, holograms, and virtual reality, which are based on traditional mobile services, have grown at an alarming speed in order to fully realize smart spaces. In order to technically support these services, the 5G mobile communication system must be developed to become more stable and continuous depending on unanimously defined requirements and performances. With more advanced technology, new services are developed and implemented at a proper time for the target customers. Thus, this study analyzed the $5 \mathrm{G}$ vision and requirements and extracted functions while also investigating the customer values offered from those functions. New service ideas were generated by considering customer values as well as technological functions, objectively and systematically compared to traditional methods of generating ideas, such as customer feedback and experts' opinions.

From an academic viewpoint, this study has the advantage of suggesting a technology-based approach with simultaneous consideration of customer values. Our study not only considered 
technological functions but also customer values using a systematic approach: morphology analysis and value innovation. Even though customers' opinions did not appear to be reflected, this research can overcome obstacles by utilizing those values that customers desire over all the cycles of buyer experience. As a result, new services were generated by increasing positive value and decreasing cost, time, and effort. Moreover, technological functions were investigated by structuralizing vision, objectives, and technical solutions using morphology analysis more systematically without relying on discussion with many researchers, thus reducing the time and effort needed to generate new services when a novel technology is first introduced.

This study intended to develop a framework for efficiently generating new service ideas, not depending on brainstorming and experts' opinion. Tools for value creation and morphology analysis enable us to exteriorize service ideas and suggest directions for satisfying target markets and customer value. The proposed framework is less affected by participant's individual ability than brainstorming or scenario planning. Scenario planning shows future conditions, events, and hypothetical futures by using a sequence of temporal images. While the scenario method focuses on managing uncertainties and forecasting a wider range of future enviroment, the proposed approach can be considered a trial of creating new concepts at the micro level.

In particular, the proposed approach can be easily applied to practical fields because it represents a systematic approach instead of relying on special creativity or intellectual ability. In particular, not much knowledge about markets is required for technology-oriented practitioners. Although a little information is needed to create a new service, the pre-defined relationship map between technology, value, and services based on the status of existing services or a hierarchy of value can assist in creating and implementing new service ideas. In addition, the systematic approach improves applicability in business by letting practitioners or researchers follow a step-by-step process to generate new service ideas. Furthermore, the novel approach can be easily utilized in other service classifications, even though this paper applied it exclusively to education services.

The proposed approach can be applied across all of a firm's departments. Previously, when new technology was about to be developed, researchers merely focused on novel functions and specifications of technology, while the marketing team regarded the applicability of the product or service without understanding the technology in detail. This can induce a failure to commercialize the new technology due to the mismatch between technology and the market, and it can give rise to a late entrance into the market, thus resulting in a significant loss of benefits and competitiveness. In addition, it will be a useful tool for planning a new business and creating a new market to adequately reflect the technical and market feasibility. Since new services were generated depending on the needs and voices of existing customers, it may be difficult to completely develop a new service concept. Moreover, if customers have no knowledge of the technology or product, incorrect forecasting of the new product and service development can ensue. That is, the proposed approach can be a good alternative for deriving novel service ideas by simultaneously regarding technological functions and customer values.

This study can contribute to making a policy related to ICT technology for smart spaces. First, 5G technology was concretely analyzed from the requirements suggested by major firms and governments; thus it will be helpful to argue and decide the regulations relevant to telecommunication by considering 5G vision, requirements and solutions as well as morphological matrix. In other words, the morphological matrix that was constructed by various organizations having expertise in $5 \mathrm{G}$ will be useful for identifying the current status of technology and service development. Secondly, the proposed approach will suggest diverse directions for new service development as well as research and development. Since in the future promising services will be proposed based on emerging technology, the results can be applied as base data when evaluating R\&D priorities or resource allocation.

Although the approach to generating technology-based service ideas was newly suggested in this study, some limitations arise in terms of the additional validation required and the simplification of 
customer values. Domain experts must be employed to validate the technological functions, and the services must be validated by a marketing team as well as technical experts. Because $5 \mathrm{G}$ technology is discussed as an advancement of $3 \mathrm{G}$ and $4 \mathrm{G}$ telecommunication, several functions and specifications have proven to be controversial, although they rely on a number of reports and technical papers. Secondly, the intention of this study was to utilize customer value at a high level, such as emotional value and epistemic value, to find a new service. However, if customer value is dealt with at a lower level, such as intelligence, happiness, and convenience, new services that satisfy these values can be determined in a concrete form. Although this study was limited to education services, more services may be identified by exploring other service categories. Thus, exploration of a wider range of services should be performed and then the novelty of the service idea needs to be evaluated in future research. Above all, future research must still use the relationship map to define relations between technology, value, and services through an analytic hierarchical process (AHP) or quality function deployment (QFD) rather than relying on the proportion of previous services; if that is the case, more reliable service concepts will be offered. In addition, another approach combinedwith scenario method will be helpful across the entire cycle of new service development because this study was limited to the idea generation process.

Acknowledgments: This work was supported by the National Research Foundation of Korea Grant funded by the Korean Government (NRF-2014S1A5A2A03065010) and Seonkoo Jeong has a master degree of Dongguk University.

Author Contributions: Seonkoo Jeong designed the study, outlined the methodology, conducted the case study, and wrote the manuscript. Yujin Jeong designed the study, conducted the case study, interpreted the results, and wrote the manuscript. Keeeun Lee conducted the case study and wrote the manuscript. Sungjoo Lee designed the study and helped interpret the results and draft the paper. Byungun Yoon implemented the research, designed the study, outlined the methodology, and helped draft the paper. All authors have read and approved the final manuscript.

Conflicts of Interest: The authors declare no conflict of interest.

\section{References}

1. Jeong, W. Smart space technology utilized by hyper-network media. In Proceedings of the 24th Korea Internet Conference, Seoul, Korea, 20-21 June 2016.

2. Milgram, P.; Kishino, F. A taxonomy of mixed reality visual displays. IEICE Trans. Inf. Syst. 1994, 77, 1321-1329.

3. Wellmann, B. Physical place and cyberplace: The rise of networked individualism. Int. J. Urban Reg. Res. 2001, 25, 227-252. [CrossRef]

4. Deloitte Touche Tohmatsu Limited; World Economic Forum. Risk and Responsibility in a Hyperconnected World—Pathways to Global Cyber Resilience; World Economic Forum: Geneva, Switzerland, 2012.

5. Parker, K.; Mainelli, M. Great mistakes in technology commercialization. Strateg. Chang. 2001, 10, 383-390. [CrossRef]

6. Conceição, P.; Hamill, D.; Pinheiro, P. Innovative science and technology commercialization strategies at 3M: A case study. J. Eng. Technol. Manag. 2002, 19, 25-38. [CrossRef]

7. Schilling, M.A. Technology success and failure in winner-take-all markets: The impact of learning orientation, timing, and network externalities. Acad. Manag. J. 2002, 45, 387-398. [CrossRef]

8. $\mathrm{Li}, \mathrm{H} . ; \mathrm{Hu}, \mathrm{B}$. Study on efficiency optimization of $\mathrm{R} \& \mathrm{D}$ resources allocation in Shanhai. Am. J. Ind. Bus. Manag. 2014, 4, 217-222.

9. Leung, C.M.; Kwok, Y.K. Real options game analysis of sleeping patents. Decis. Econ. Financ. 2011, 34, 41-65. [CrossRef]

10. Cincera, M.; Czarnitzki, D.; Thorwarth, S. Efficiency of Public Spending in Support of RED Activities; Directorate General Economic and Monetary Affairs (DG ECFIN); European Commission: Brussels, Belgium, 2009.

11. An, H.J.; Ahn, S.-J. Emerging technologies-Beyond the chasm: Assessing technological forecasting and its implication for innovation management in Korea. Technol. Forecast. Soc. Chang. 2016, 102, 132-142. [CrossRef] 
12. Peng, Y.-N.; Sanderson, S.W. Crossing the chasm with beacon products in the portable music player industry. Technovation 2014, 34, 77-92. [CrossRef]

13. Matthing, J.; Kristensson, P.; Gustafsson, A. Developing successful technology-based services: The issue of identifying and involving innovative users. J. Serv. Mark. 2006, 20, 288-297. [CrossRef]

14. Alm, I.; Perry, C. A customer-oriented new service development process. J. Serv. Mark. 2002, 16, 515-534. [CrossRef]

15. Martin, C.R.; Horne, D.A. Level of success inputs for service innovations in the same firm. Int. J. Serv. Ind. Manag. 1995, 6, 40-56.

16. Gordon, G.; Kaminski, P.; Calantone, R.; Benedetto, A.D. Linking customer knowledge with successful service innovation. J. Appl. Bus. Res. 1993, 9, 129-139. [CrossRef]

17. Kim, W.C.; Mauborgne, R. Value innovation: A leap into the blue ocean. J. Bus. Strategy 2005, 26, 22-28.

18. Kim, W.C.; Mauborgne, R. Value innovation-The strategic logic of high growth. Harv. Bus. Rev. 1997, 75, 102-112. [PubMed]

19. Nemet, G.F. Demand-pull, technology-push, and government-led incentives for non-incremental technical change. Res. Policy 2009, 38, 700-709. [CrossRef]

20. Brem, A.; Voigt, K.-I. Integration of market pull and technology push in the corporate front end and innovation management-Insights from the German software industry. Technovation 2009, 29, 351-367. [CrossRef]

21. Gerpott, T.J. Strategisches Technologie-und Innovationsmanagement; Schäffer-Poeschel Verlag: Stuttgart, Germany, 2005. (In German)

22. Burgelman, R.; Sayles, L. Transforming Invention into Innovation: The Conceptualization Stage; Strategic Management of Technology and Innovation; McGraw-Hill: Boston, MA, USA, 2004; pp. 682-690.

23. Walsh, S.T.; Kirchhoff, B.A.; Newbert, S. Differentiating market strategies for disruptive technologies. IEEE Trans. Eng. Manag. 2002, 49, 341-351. [CrossRef]

24. Di Stefano, G.; Gambardella, A.; Verona, G. Technology push and demand pull perspectives in innovation studies: Current findings and future research directions. Res. Policy 2012, 41, 1283-1295. [CrossRef]

25. Nijssen, E.J.; Hillebrand, B.; Vermeulen, P.A.; Kemp, R.G. Exploring product and service innovation similarities and differences. Int. J. Res. Mark. 2006, 23, 241-251. [CrossRef]

26. Griffin, A. PDMA research on new product development practices: Updating trends and benchmarking best practices. J. Prod. Innov. Manag. 1997, 14, 429-458. [CrossRef]

27. Möller, K.; Rajala, R.; Westerlund, M. Service innovation myopia? A new recipe for client-provider value creation. Calif. Manag. Rev. 2008, 50, 31-48. [CrossRef]

28. Candi, M. The role of design in the development of technology-based services. Des. Stud. 2007, 28, 559-583. [CrossRef]

29. Van Riel, A.C.R.; Semeijn, J.; Hammedi, W.; Henseler, J. Technology-based service proposal screening and decision-making effectiveness. Manag. Decis. 2011, 49, 762-783. [CrossRef]

30. Knot, E.A.R.; van den Ende, J.; Vergragt, P. Flexibility strategies for sustainable technology development. Technovation 2001, 21, 335-343. [CrossRef]

31. Lee, E.; Lee, J.; Eastwood, D. A two-step estimation of consumer adoption of technology-based service innovations. J. Consum. Aff. 2003, 37, 256-282. [CrossRef]

32. Urban, G.L.; Hauser, J.R. Design and Marketing of New Products, 2nd ed.; Prentice Hall: Englewood Cliffs, NJ, USA, 1993.

33. Cooper, R.G. Winning at New Products: Accelerating the Process from Idea to Launch; Addison-Wesley Publishing Co.: Boston, MA, USA, 2001.

34. Ahn, J.-H.; Skudlark, A. Managing risk in a new telecommunications service development process through a scenario planning approach. J. Inf. Technol. 2002, 17, 103-118. [CrossRef]

35. Oh, Y.; Suh, E.-H.; Hong, J.; Hwang, H. A feasibility test model for new telecom service development using MCDM method: A case study of video telephone service in Korea. Expert Syst. Appl. 2009, 36, 6375-6388. [CrossRef]

36. Ernst \& Young Global Limited (EYGM). Global Telecommunications Study: Navigating the Road to 2020; EYGM Limited: Los Angeles, CA, USA, 2015. 
37. Robles, T.; Mitjana, E.; Ruiz, P. Usage scenarios and business opportunities for systems beyond 3G. In Proceedings of the IST Mobile and Wireless Telecommunications Summit 2002, Thessaloniki, Greece, 16-19 June 2002.

38. METIS Project. Scenarios, Requirements and KPIs for 5G Mobile and Wireless System; The METIS 2020 Project: Stockholm, Sweden, 2013.

39. Nokia Oyj. 5G Use Cases and Requirements; Nokia Co.: Espoo, Finland, 2014.

40. Kim, S.; Yoon, B. A systematic approach for new service concept generation: Application of agent-based simulation. Expert Syst. Appl. 2014, 41, 2793-2806. [CrossRef]

41. Lee, C.; Song, B.; Park, Y. Generation of new service concepts: A morphology analysis and genetic algorithm approach. Expert Syst. Appl. 2009, 36, 12454-12460. [CrossRef]

42. Matthing, J.; Sandén, B.; Edvardsson, B. New service development: Learning from and with customers. Int. J. Serv. Ind. Manag. 2004, 15, 479-498. [CrossRef]

43. Alam, I. An exploratory investigation of user involvement in new service development. J. Acad. Mark. Sci. 2004, 30, 250-261. [CrossRef]

44. Kim, C.; Jeon, J.-H.; Kim, M.-S. Identification and Management of opportunities for technology-based services: A patent-based portfolio approach. Innov. Manag. Policy Pract. 2015, 17, 232-249. [CrossRef]

45. Luo, J.; Olechowski, A.L.; Magee, C.L. Technology-based design and sustainable economic growth. Technovation 2014, 34, 663-677. [CrossRef]

46. Hertenstein, J.H.; Platt, M.B.; Veryzer, R.W. The impact of industrial design effectiveness on corporate financial performance. J. Prod. Innov. Manag. 2005, 22, 3-21. [CrossRef]

47. Walsh, V. Design, innovation and the boundaries of the firm. Res. Policy 1996, 25, 509-529. [CrossRef]

48. Kim, W.C.; Mauborgne, R. Strategy, value innovation, and the knowledge economy. MIT Sloan Manag. Rev. 1999, 40, 41-54.

49. Rogers, E.M. Diffusion of Innovations; Simon and Schuster: New York, NY, USA, 2010.

50. Hargadon, A.; Sutton, R.I. Technology brokering and innovation in a product development firm. Adm. Sci. Q. 1997, 42, 716-749. [CrossRef]

51. Altshuller, G.; Shulyak, L.; Rodman, S. The Innovation Algorithm: TRIZ, Systematic Innovation and Technical Creativity; Technical Innovation Center, Inc.: Worcester, MA, USA, 1999.

52. Yamashina, H.; Ito, T.; Kawada, H. Innovative product development process by integrating QFD and TRIZ. Int. J. Prod. Res. 2002, 40, 1031-1050. [CrossRef]

53. Zhang, J.; Tan, K.C.; Chai, K.H. Systematic innovation in service design through TRIZ. In Proceedings of the EurOMA-POMS Annual Conference, Lake Como, Italy, 16-18 June 2003.

54. Magnusson, P.R.; Matthing, J.; Kritensson, P. Managing user involvement in service innovation: Experiments with innovating end users. J. Serv. Res. 2003, 6, 111-124. [CrossRef]

55. Thomke, S.; Hippel, E.V. Customers as innovators: A new way to create value. Harv. Bus. Rev. 2002, 80, 74-81.

56. Olson, E.L.; Bakke, G. Implementing the lead user method in a high technology firm: A longitudinal study of intentions versus actions. J. Prod. Innov. Manag. 2001, 18, 388-395. [CrossRef]

57. Kim, W.C.; Mauborgne, R. Blue Ocean Strategy; Harvard Business Review Press: Watertown, MA, USA, 2005.

58. Kim, W.C.; Mauborgne, R. Blue ocean strategy: From theory to practice. Calif. Manag. Rev. 2005, 47, $105-121$. [CrossRef]

59. Chaoren, L.; Thawatthatree, A. Use Value Innovation to Create Competitive Advantages in Blue Ocean: A Case Study of IKEA in Nanjing. Master's Thesis, Karlstad University, Karlstad, Sweden, 2015.

60. Keränen, J.; Jalkala, A. Three strategies for customer value assessment in business markets. Manag. Decis. 2014, 52, 79-100. [CrossRef]

61. Landroguez, S.M.; Castro, C.B.; Cepeda-Carrión, G. Creating dynamic capabilities to increase customer value. Manag. Decis. 2011, 49, 1141-1159. [CrossRef]

62. Woodruff, R.B. Customer value: The next source for competitive advantage. J. Acad. Mark. Sci. 1997, 25, 139-153. [CrossRef]

63. Eggert, A.; Ulaga, W. Customer perceived value: A substitute for satisfaction in business markets? J. Bus. Ind. Mark. 2002, 17, 107-118. [CrossRef]

64. Grönroos, C. A service perspective on business relationships: The value creation, interaction and marketing interface. Ind. Mark. Manag. 2011, 40, 240-247. [CrossRef] 
65. Lai, A.W. Consumer values, product benefits and customer value: A consumption behavior approach. Adv. Consum. Res. 1995, 22, 381-388.

66. Kim, W.C.; Mauborgne, R. Knowing a winning business idea when you see one. Harv. Bus. Rev. 2000, 78, 129-138. [CrossRef]

67. Kabukin, D. Reviewing the Blue Ocean Strategy. Is the Blue Ocean Strategy Valid and Reliable? Master's Thesis, University of Twente, Enschede, The Netherlands, 2014.

68. Sheehan, N.T.; Bruni-Bossio, V. Strategic value curve analysis: Diagnosing and improving customer value propositions. Bus. Horiz. 2015, 58, 317-324. [CrossRef]

69. Mohamed, Z.A.; Hilman, H.; Bahaman, U.S. The blue ocean strategy; Case study analysis of its implementation in 14 different agencies in Malaysia. Dev. Ctry. Stud. 2014, 4, 105-119.

70. Wenzel, H.; Förster, A. Blue Ocean Strategy: How IKEA Created a New Market; Grin Verlag (GRIN): München, Germany, 2013.

71. Kano, N.; Seraku, N.; Takahashi, F.; Tsuji, S. Attractive quality and must be quality. Quality 1984, 14, $39-48$.

72. Cohen, L. Quality Function Deployment; Prentice Hall: Englewood Cliffs, NJ, USA, 1995.

73. Zwicky, F. Discovery, Invention, Research-Through the Morphological Approach; Macmilan Company: New York, NY, USA, 1969.

74. Hall, A.D. Three-dimensional morphology of systems engineering. In Contributions to a Philosophy of Technology; Springer: Amsterdam, The Netherlands, 1969; pp. 174-186.

75. Feng, X.; Fuhai, L. Patent text mining and informetric-based patent technology morphological analysis-An empirical study. Technol. Anal. Strateg. Manag. 2012, 24, 467-479. [CrossRef]

76. Ritchey, T. Modelling alternative futures with general morphological analysis. World Future Rev. 2011, 3, 83-94. [CrossRef]

77. Ritchey, T. Fritz Zwicky, morphologie and policy analysis. In Proceedings of the 16th EURO Conference on Operational Analysis, Brussels, Belgium, 29-31 May 1998.

78. Prokopska, A. Application of morphological analysis methodology in architectural design. Acta Polytech. 2001, 41, 46-54.

79. Medina, G.V.; Pham, M.T.; Marquis-Favre, W. A modified Zwicky's morphological analysis: Application to the design of a robotic laparoscope. In Proceedings of the 4th European Conference of the International Federation for Medical and Biological Engineering, Antwerp, Belgium, 23-27 November 2009.

80. Song, M.J.; Lee, J.-G.; Park, J.-M.; Lee, S. Triggering navigators for innovative system design: The case of lab-on-a-chip technology. Expert Syst. Appl. 2012, 39, 12451-12459. [CrossRef]

81. Im, K.; Cho, H. A systematic approach for developing a new business model using morphological analysis and integrated fuzzy approach. Expert Syst. Appl. 2013, 40, 4463-4477. [CrossRef]

82. Yoon, B.; Park, Y. A systematic approach for identifying technology opportunities: Keyword-based morphology analysis. Technol. Forecast. Soc. Chang. 2005, 72, 145-160. [CrossRef]

83. Yoon, B. On the development of a technology intelligence tool for identifying technology opportunity. Expert Syst. Appl. 2008, 35, 124-135. [CrossRef]

84. Yoon, B.; Park, Y. Development of new technology forecasting algorithm: Hybrid approach for morphology analysis and conjoint analysis of patent information. IEEE Trans. Eng. Manag. 2007, 54, 588-599. [CrossRef]

85. Yoon, B.; Phaal, R.; Probert, D. Morphology analysis for technology roadmapping: Application of text mining. RED Manag. 2013, 40, 51-68.

86. Rokeach, M. The Nature of Human Values; Free Press: New York, NY, USA, 1973.

87. Škudienė, V.; Nedzinskas, Š.; Ivanauskienè, N.; Auruškevičienè, V. Customer perceptions of value: Case of retail banking. Organ. Mark. Emerg. Econ. 2012, 3, 75-88.

88. Tehrani, M.N.; Uysal, M.; Yanikomeroglu, H. Device-to-device communication in 5G cellular networks: Challenges, solutions, and future directions. IEEE Commun. Mag. 2014, 52, 86-92. [CrossRef]

89. Wu, S. Application of D2D in 5G networks. ZTE Technol. 2015, 17, 158.

90. Lin, X.; Ratasuk, R.; Ghosh, A.; Andrews, J.G. Modeling, analysis, and optimization of multicast device-to-device transmissions. IEEE Trans. Wirel. Commun. 2015, 13, 4346-4359. [CrossRef]

91. Phunchongharn, P.; Hossain, E.; Kim, D.I. Resource allocation for device-to-device communications underlaying LTE-Advanced networks. IEEE Wirel. Commun. 2013, 20, 91-100. [CrossRef]

92. ATutor. ATutor Learning Management Tools. Available online: www.atutor.ca (accessed on 1 November 2016).

93. Edmodo. Online Learning Programs. Available online: www.edomodo.com (accessed on 1 November 2016). 
94. Sakai. Features of Sakai. Available online: https://www.sakaiproject.org/node/1377 (accessed on 1 November 2016).

95. Sumtotal. The Latest SumTotal Talent Expansion Suite Is Here. Available online: http://www. sumtotalsystems.com/winter2016/ (accessed on 1 November 2016).

96. Capterra. Top LMS Software. Available online: http://elearninginfographics.com/top-lmssoftware-infographic/?utm_campaign=elearningindustry.com\&utm_source=\%2Fthe-20-best-learningmanagement-systems\&utm_medium=link (accessed on 14 October 2016).

97. Graf, S.; List, B. An evaluation of open source e-learning platforms stressing adaptation issues. In Proceedings of the 5th IEEE International Conference on Advanced Learning Technologies (ICALT'05), Kaohsiung, Taiwan, 5-8 July 2005; pp. 163-165.

98. Dagger, D.; O'Connor, A.; Lawless, S.; Walsh, E.; Wade, V.P. Service-oriented e-Learning platforms: From monolithic systems to flexible services. IEEE Internet Comput. 2007, 11, 28-35. [CrossRef]

(C) 2016 by the authors; licensee MDPI, Basel, Switzerland. This article is an open access article distributed under the terms and conditions of the Creative Commons Attribution (CC-BY) license (http://creativecommons.org/licenses/by/4.0/). 